\title{
Casting alloys: The saga of their existence and the recipe of their blend
}

\author{
Guduri Vineeth1, ${ }^{*}$, Rama Krishna Alla², Srinivasa Raju D ${ }^{3}$, Suresh Sajjan MC4, Ramaraju AV4, Harika \\ Yeleti5,
}

${ }^{1}$ Senior Lecturer, Department of Prosthodontics, Vishnu Dental College, Bhimavaram, West Godavari, 534202, Andhra Pradesh, India.

${ }^{2}$ Assistant Professor, Department of Dental Materials, Vishnu Dental College, Bimavaram, West Godavari, 534202, Andhra Pradesh, India.

${ }^{3}$ Professor, Department of Dentistry, Maharaja Institute of Medical Sciences, Nellimarala, Vizainagaram, Andhra Pradesh, India.

${ }^{4}$ Professor, Department of Prosthodontics, Vishnu Dental College, Bhimavaram, West Godavari, 534202, Andhra Pradesh, India.

5Senior Lecturer, Department of Prosthodontics, Lenora Institute of Dental Sciences, Rajahmundry, East Godavari District, Andhra Pradesh 533294, India.

I N $\begin{array}{lllllllll} & \text { F O R } & \text { M A A } & \text { T I O } & \text { N }\end{array}$

\section{Article History}

Received 28 April 2019

Received revised

11 May 2019

Accepted 13 May 2019

Available online 15 May 2019

\section{K E Y W O R D S}

Alloy
Casting
Noble metal
Base metal
Nickel
Chromium,
Titanium,
Beryllium
OSHA
NIOSH

\section{A B S T R A C T}

Though a variety of metals and combinations have been in use since decades in the field of dentistry, there are only a few which have sustained the challenges of evolving material science. The history of these alloys, their constituent metals and properties impart the rationale of their use both in the past and advancing future perspectives. Also bearing the environmental hazards in laboratory and clinical environments, safe levels of exposure to these alloys and aspects of selecting the best option among the different alternatives is important.

\section{Introduction}

In dentistry, metals represent one of the four major classes of materials used for the reconstruction of damaged or missing oral tissues while the others being ceramics, polymers and composites [1]. But the question is whether we really use pure metals in dentistry or not. With the exceptions of pure gold foil, commercially pure titanium and endodontic silver points, all the other metallic substances used in dentistry are alloys [1]. The reason for this occurrence is that pure metals fail to meet the desirable properties individually [2]. So, alloys provided the best means to alter the properties of individual metals into desirable characteristics. (Note: The word 'metal' is used as a generalized term for metals and alloys in the field of dentistry). In spite of the advancements in ceramics and increasing demand of esthetics over durability, the role of alloys in dentistry still remains prominent because of their extraordinary combination of strength, wear resistance, biologic compatibility and long-term survival [3]. 
Metals form the building blocks of an alloy in innumerable combinations and proportions but those suitable for intraoral biocompatibility are limited and are enlisted in Table 1.

\section{History of metals in dentistry}

Dentistry as a specialty is believed to have begun about 3000 BC. Gold bands and wires were used by the Phoenicians after 2500 BC [4]. Modern dentistry began in 1728 when Fauchard published different treatment modalities describing many types of dental restorations, including a method for the construction of artificial dentures made from ivory and metals. Gold shell crowns were described by Mouton in 1746 but they were not patented until in 1873 by Beers. In 1885, Logan patented porcelain fused to platinum post replacing the unsatisfactory wooden post previously used to build up intra-radicular areas of teeth [5]. The other important events in the evolution of dentistry are given Table 2 .

\section{Ideal requirements of alloys in dentistry [1, 6-8]}

The dental casting alloys should possess certain requirements in order to use them in the oral cavity for various purposes. The ideal requirements of various dental casting alloys are discussed in Table 3 .

\section{Alloy constituents}

Alloy is defined as a mixture of two or more metals or metalloids that are mutually soluble in the molten state; distinguished as binary, ternary, quaternary, etc. which again based on the miscibility is divided as solid solution, eutectic, peritectic and intermetallic types. Several alloys have been used in dentistry out of which eutectic and peritectic alloys are utilized maximum. But these metals cannot be mixed into one another in the conventional process, but require heat treatments in order to formulate and obtain the desired properties of the alloys [1].

\subsection{Heat treatment of gold alloys $[1,8-10]$}

Heat treatment of alloys is done in order to alter its mechanical properties. Gold alloys can be heat treated if it contains sufficient amount of copper. Only type III and type IV gold alloys can be heat-treated. There are two types of heat treatment such as softening heat treatment (solution heat treatment) and hardening heat treatment (age hardening).

Softening heat treatment increased ductility, but reduces tensile strength, proportional limit, and hardness [8]. It is indicated for appliances that are to be grounded, shaped, or otherwise cold worked in or outside the mouth. In this process, the casting is placed in an electric furnace for 10 minutes at a temperature of $700^{\circ} \mathrm{C}$ and then it is quenched in water. During this period, all intermediate phases are presumably changed to a disordered solid solution, and the rapid quenching prevents ordering from occurring during cooling. Each alloy has its optimum temperature [8]. The manufacturer should specify the most favorable temperature and time.

Hardening heat treatment increases strength, proportional limit, and hardness, but decreases ductility. It is the copper present in gold alloys, which helps in the age hardening process [9]. It is indicated for metallic partial dentures, saddles, bridges and other similar structures. It is not employed for smaller structures such as inlays.

Hardening het treatment is done by "soaking" or ageing the casting at a specific temperature for a definite time, usually 15 to 30 minutes. It is then water quenched or cooled slowly. The aging temperature depends on the alloy composition but is generally between $200^{\circ} \mathrm{C}$ and $450^{\circ} \mathrm{C}$. During this period, the intermediate phases are changed to an ordered solid solution. The proper time and temperature for age hardening an alloy are specified by the manufacturer.

Ideally, before age hardening an alloy, it should first be subjected to a softening heat treatment to relieve all strain hardening \& to start the hardening treatment when the alloy is in a disordered solid solution [10]. This allows better control of the hardening process.

\section{Classification}

Dental casting alloys are classified in to various types and they are discussed in the subsequent sections from 5.1. to 5.3 . 


\begin{tabular}{|c|c|c|c|c|c|c|}
\hline Metal & Metal type & $\begin{array}{l}\text { Density } \\
\left(\mathrm{g} / \mathrm{cm}^{3}\right)\end{array}$ & $\begin{array}{c}\text { Melting } \\
\text { point }\left({ }^{\circ} \mathrm{C}\right)\end{array}$ & $\begin{array}{c}\text { Boiling } \\
\text { point }\left({ }^{\circ} \mathrm{C}\right)\end{array}$ & $\begin{array}{c}\mathrm{CTE}^{*} \\
\left(\times 10^{-6} /{ }^{\circ} \mathrm{C}\right)\end{array}$ & Functions \\
\hline Gold $(\mathrm{Au})$ & Noble metal & 19.3 & 1063 & 2970 & 14.2 & $\begin{array}{l}\text { Imparts ductility, } \\
\text { improves tarnish and } \\
\text { corrosion resistance }\end{array}$ \\
\hline Silver (Ag) & $\begin{array}{l}\text { Precious metal } \\
\text { (not considered } \\
\text { noble anymore) }\end{array}$ & 10.4 & 961 & 2216 & 19.7 & $\begin{array}{l}\text { Strengthener, harden- } \\
\text { er, whitens the alloy, } \\
\text { increases CTE }\end{array}$ \\
\hline Palladium (Pd) & Noble metal & 12.02 & 1552 & 3980 & 11.8 & $\begin{array}{l}\text { Hardener, tarnish } \\
\text { resistance, whitens the } \\
\text { alloy, increases fusion } \\
\text { temp. }\end{array}$ \\
\hline Platinum (Pt) & Noble metal & 21.45 & 1769 & 4530 & 8.9 & $\begin{array}{l}\text { Strengthener, corrosion } \\
\text { resistance, whitens the } \\
\text { alloy, increases melting } \\
\text { temp., grain refiner }\end{array}$ \\
\hline Nickel (Ni) & Base metal & 8.9 & 1453 & 4530 & 13.3 & $\begin{array}{l}\text { Hardener, } \\
\text { Strengthener, } \\
\text { whitens the alloy. }\end{array}$ \\
\hline Cobalt (Co) & Base metal & 8.85 & 1495 & 2900 & 13.8 & $\begin{array}{l}\text { Strengthener, } \\
\text { Hardener }\end{array}$ \\
\hline Chromium (Cr) & Base metal & 7.19 & 1907 & 2671 & 6.2 & Passivation effect \\
\hline Copper $(\mathrm{Cu})$ & Base metal & 8.96 & 1083 & 2595 & 16.5 & $\begin{array}{l}\text { Hardener, } \\
\text { Increases melting point }\end{array}$ \\
\hline Molybdenum (Mo) & Base metal & 10.28 & 2623 & 4639 & 4.8 & $\begin{array}{l}\text { Hardener, Strengthener, } \\
\text { refractory material, cor- } \\
\text { rosion resistance, grain } \\
\text { refiner }\end{array}$ \\
\hline Iron $(\mathrm{Fe})$ & Base metal & 7.87 & 1527 & 3000 & 12.3 & Hardener \\
\hline Manganese (Mn) & Base metal & 1.74 & 650 & 1107 & 25.2 & $\begin{array}{l}\text { Oxide scavenger, in- } \\
\text { creases CTE, whitens } \\
\text { the alloy }\end{array}$ \\
\hline Silicon (Si) & Metalloid & 2.33 & 1410 & 2480 & 7.3 & Hardener \\
\hline
\end{tabular}

Table 1: Various metals used for alloying. *Coefficient of thermal expansion.

Other noble metals - Iridium (Ir), Ruthenium (Ru), Rhodium (Rh), Osmium (Os) which act as grain refiners are added in small quantities.

Zinc (Zn) is a bluish white metal which acts as a scavenger for oxygen.

Gallium (Ga) used to decrease the co-efficient of thermal expansion is added in moderate amounts in silver free alloys and very minute amounts in silver containing alloys.

Beryllium (Be) though added to decrease fusion temperature and refines grain size poses a occupational hazard to the dental lab technicians.

Non-metals used for alloying: Carbon and boron are the two common non-metals used for alloying. While carbon increases strength, boron decreases the melting temperature, ductility and acts as a de-oxidizer. 


\begin{tabular}{|c|c|}
\hline Year & Event \\
\hline 1907 & Introduction of Lost-Wax Technique \\
\hline 1933 & Replacement of Co-Cr for Gold in Removable Partial Dentures \\
\hline 1950 & Development of Resin Veneers for Gold Alloys \\
\hline 1959 & Introduction of the Porcelain Fused-to-Metal Technique \\
\hline 1968 & Palladium-Based Alloys as Alternatives to Gold Alloy \\
\hline 1971 & Nickel-Based Alloys as Alternatives to Gold Alloys \\
\hline 1980 s & Introduction of All-Ceramic Technologies \\
\hline 1999 & Gold Alloys as Alternatives to Palladium-Based Alloys \\
\hline 1971 & $\begin{array}{l}\text { The Gold Standard: The United States abandoned the gold standard in } 1971 . \text { Gold then became } \\
\text { a commodity freely traded on the open markets. As a result, the price of gold increased steadily } \\
\text { over the next nine years. In response to the increasing price of gold, new dental alloys were } \\
\text { introduced through the following changes: } \\
\text { - In some alloys, gold was replaced with palladium. } \\
\text { - In other alloys, palladium eliminated gold entirely. } \\
\text { - Base metal alloys with nickel as the major element eliminated the exclusive need for noble } \\
\text { metals. }\end{array}$ \\
\hline 1976 & Dental alloys were classified as passive implants by the Medical and Dental devices act. \\
\hline 1980 & Introduction of All-ceramic technologies. \\
\hline 1996 & $\begin{array}{l}\text { The European Medical Devices Directive established the imposition of CE mark on any imports } \\
\text { of dental devices. }\end{array}$ \\
\hline 1998 & Gold alloys as alternatives to Palladium based alloys due to the Clean Air acts. \\
\hline
\end{tabular}

\section{Table 2: Important historical events in the evolution of alloys in dentistry}

5.1. ADA specification No. 5 classified dental gold casting alloys as [11-13]

- High Gold Alloys Type I - Soft - inlays, Class III and V restorations Type II - Medium - thick $3 / 4^{\text {th }}$ crowns, pontics etc. Type III - Hard - full crowns, short span FPDs etc. Type IV - Extra hard - long span FPDs, partial denture frameworks etc.

- Low Gold Alloys

- White Gold Alloys

The hardness, proportionality limit and strength increase from Type I to Type IV whereas ductility and corrosion resistance decreases in the similar order.

5.2. On the basis of nobility the casting alloys have been divided into
- High Noble metal alloys - require at least 60 weight percentage (wt\%) and a gold content of at least $40 \%$.

- Noble metal alloys - require noble metal content at least $25 \mathrm{wt} \%$ (no stipulation for gold).

- Predominantly Base metal alloys - require noble metal content less than $25 \mathrm{wt} \%$.

- Titanium and Titanium alloys - require at least 85 wt $\%$ of titanium content.

\subsection{On the basis of their application}

Two types of alloys based on their applications in dentistry. They include All-metal alloys and metal-ceramic alloys. Metal-Ceramic alloys have paved the gateway of esthetics along with the durability of that of the alloyed metals. The main function of metal-ceramic alloys is to reinforce porcelain, thus increasing its resistance to fracture. 


\begin{tabular}{|c|c|}
\hline Properties & Ideal Requirement \\
\hline Biological & $\begin{array}{l}\text { - Should be biocompatible. } \\
\text { - Should not contain allergenic components. } \\
\text { - Should not be irritant to the tissues. } \\
\text { - Should not be toxic to the tissues. } \\
\text { - Should not be carcinogenic or mutagenic. }\end{array}$ \\
\hline Chemical & $\begin{array}{l}\text { - Should be tarnish resistant. } \\
\text { - Should be corrosion resistant. } \\
\text { - Should be able to bond with porcelain. } \\
\text { - Should have the ability to be etched. }\end{array}$ \\
\hline Physical & $\begin{array}{l}\text { - Should have enough strength. } \\
\text { - Should be hard enough to facilitate } \\
\text { - Finishing and polishing and yet have sufficient } \\
\text { - Wear resistance } \\
\text { - Should have optimum ductility in cases of RPD frameworks. }\end{array}$ \\
\hline Thermal & $\begin{array}{l}\text { - Should have a narrow melting range. } \\
\text { Solidus temperature: Temperature at which an alloy becomes solid on } \\
\text { cooling or at which the metal begins to melt on heating. } \\
\text { Liquidus temperature: Temperature at which an alloy begins to freeze on } \\
\text { cooling or at which the metal is completely molten on heating. } \\
\text { - Should have good castability. } \\
\text { - Should be easy for brazing and soldering. } \\
\text { - Should have less solidification shrinkage. } \\
\text { - Should have enough sag resistance. } \\
\text { - Should have co-efficient of thermal expansion closer to porcelains. }\end{array}$ \\
\hline Miscellaneous & $\begin{array}{l}\text { - Should be inexpensive. } \\
\text { - Should not discolor the overlying porcelain. }\end{array}$ \\
\hline
\end{tabular}

The alloys used for metal-ceramic purposes are grouped under two categories including noble metal alloys and base metal alloys. In case of noble metal alloys for porcelain bonding, addition of $1 \%$ base metals (iron, indium, tin etc.) increases porcelain-metal bond strength, which is due to formation of an oxide film on its surface. It also increases strength and proportional limit. The different metallic combinations available as per nobility are summarized in Table 4. $[14,15]$.

\subsection{Noble metal alloys}

The desired properties of noble metal alloys determine the selection of elements that constitute the alloys. These were the first alloys to be brought into usage in the field of dentistry. The reason for their selection may be due to their availability and their inertness towards the oral environment. Listed below are a few of the commonly used noble metal alloys-

\subsection{Gold-Platinum-Palladium (Au-Pt-Pd)} System 


\begin{tabular}{|c|c|c|c|}
\hline Alloy type & All-metal & Metal-ceramic & $\begin{array}{l}\text { Removable Partial Den- } \\
\text { ture alloys }\end{array}$ \\
\hline High Noble metal & $\begin{array}{l}\mathrm{Au}-\mathrm{Ag}-\mathrm{Cu}-\mathrm{Pd} \\
\mathrm{Au}-\mathrm{Ag}-\mathrm{Pd} \\
\text { High noble metal ce- } \\
\text { ramic alloys }\end{array}$ & $\begin{array}{l}\text { Pure Au (99.7 wt\%) } \\
\text { Au-Pt-Pd } \\
\text { Au-Pd-Ag } \\
\text { (both } 5-12 w t \% \text { and >12wt\% } \\
\text { Ag) } \\
\text { Au-Pd }\end{array}$ & $\mathrm{Au}-\mathrm{Ag}-\mathrm{Cu}-\mathrm{Pd}$ \\
\hline Noble metal & $\begin{array}{l}\text { Ag-Pd-Au-Cu } \\
\text { Ag-Pd } \\
\text { Noble metal ceramic alloys }\end{array}$ & $\begin{array}{l}\mathrm{Pd}-\mathrm{Au} \\
\mathrm{Pd}-\mathrm{Au}-\mathrm{Ag} \\
\mathrm{Pd}-\mathrm{Ag} \\
\mathrm{Pd}-\mathrm{Cu}-\mathrm{Ga} \\
\mathrm{Pd}-\mathrm{Ga}-\mathrm{Ag}\end{array}$ & \\
\hline $\begin{array}{l}\text { Predominantly Base } \\
\text { metal }\end{array}$ & $\begin{array}{l}\text { CP Ti } \\
\text { Ti-Al-V } \\
\text { Ni-Cr-Mo-Be } \\
\text { Ni-Cr-Mo } \\
\text { Co-Cr-Mo } \\
\text { Co-Cr-W } \\
\text { Cu-Al }\end{array}$ & $\begin{array}{l}\text { CP Ti } \\
\text { Ti-Al-V } \\
\text { Ni-Cr-Mo-Be } \\
\text { Ni-Cr-Mo } \\
\text { Co-Cr-Mo } \\
\text { Co-Cr-W }\end{array}$ & $\begin{array}{l}\text { CP Ti } \\
\text { Ti-Al-V } \\
\text { Ni-Cr-Mo-Be } \\
\text { Ni-Cr-Mo } \\
\text { Co-Cr-Mo } \\
\text { Co-Cr-W }\end{array}$ \\
\hline
\end{tabular}

\section{Table 4. Different alloy types available to suit the purpose classified according to nobility}

These alloys were developed in an attempt to overcome the major limitations in the gold-platinumpalladium system. Poor sag resistance, low hardness \& high cost, two variations on the basic combination of gold, palladium and silver were created and are identified as the either the high-silver.

The high silver alloy contains Gold (39\% to 53\%), Palladium (25\% to $35 \%)$ and Silver (12\% to $22 \%$ ) including trace amounts of oxidizable elements are added for porcelain bonding. While The low silver alloys comprise increased Gold (52\% to $77 \%$ ) content and decreased Silver (5\% to $12 \%$ ) and Palladium (10\% to $33 \%$ ) content along with trace amounts of oxidizable elements for porcelain bonding.

These alloys improved the rigidity and sag resistance while maintaining the high nobility, co-efficient of thermal expansion and corrosion resistance while managing to keep the cost relatively cheaper than that of the Au-Pt-Pd alloys. These expensive alloys have high silver content that creates potential for porcelain discoloration.

\subsection{Palladium-Silver (Pd-Ag) System}

This was the first gold free system to be introduced in the United States (1974) that still contained a noble metal (palladium) [18]. It was offered as an economical alternative to the more expensive gold-platinum-silver and gold-palladium-silver (gold based) metals.

The low silver containing group consist of Palladium (55\% to $60 \%$ ), Silver (25\% to $30 \%$ ) and Indium and Tin in trace amounts while the high silver group is made of Palladium (50\% to 55\%), Silver (35\% to 40\%) with Tin, little or no Indium and trace elements of other oxidizable base elements.

These less dense alloys exhibit good tarnish and corrosion resistance in spite of the moderate nobility and also show good porcelain bonding and excellent sag resistance. These are suitable for long span fixed partial dentures and are cost effective. The alloys are prone to discolor the porcelain and have low hardness. They adsorb gases and hence should not be cast in carbon crucible.

\section{4. Gold-Palladium (Au-Pd) System}

This particular system was developed in an attempt to overcome the major limitations in the gold - platinum - 
silver system and Pd-Ag alloys namely; Porcelain discoloration and too high coefficient of thermal expansion \& contraction.

These have decreased gold but increased palladium content. They contain indium for bonding, gallium and (Ga) to decrease the fusion temperature. These alloys are stronger, stiffer, and harder than the Au-Pt-Pd alloys and have higher elongation (more ductile) and casting temperatures (easier to solder).

These alloys are composed of Gold (44\% to 55\%), Palladium (35\% to $45 \%$ ), Gallium (5\%), Indium \& Tin ( $8 \%$ to $12 \%$ ) and traces of grain refining elements. The alloys exhibit excellent castability, good bond strength and corrosion resistance, improved hardness and strength but have low density. These are not thermally compatible with high expansion dental porcelains and are expensive.

\section{5. High Palladium System}

Several types of high palladium were originally introduced (Tuccillo, 1987) [19]. More popular composition, group containing cobalt and the other containing copper. Copper appears to be more popular. These white alloys have high strength and hardness, good stiffness and elongation, and low density. However, they have low sag resistance and form dark oxides.

The cobalt containing alloy comprises of Palladium (78\% to $88 \%$ ), Cobalt ( $4 \%$ to $10 \%$ ) with gold (2\%) added in some alloys and trace amounts of oxidizable elements (such as gallium and indium) are added for porcelain bonding. On the other hand, the copper containing alloy contains Palladium (70\% to $80 \%)$, Copper ( $9 \%$ to $15 \%$ ) and trace amounts of the oxidizable elements gallium, indium and tin are added for porcelain bonding with Gold (1\% to $2 \%$ ) and Platinum (1\%) added sometimes.

The alloys of this system show good castability, sag resistance, corrosion resistance, high hardness and low density. On the other side, the alloys adsorb gases forming thick oxides and hence pose a problem of discoloring the porcelain.

\subsection{Recycling Noble Metal Casting Alloy [20]}

The alloy scrap should be recycled because of the high value of the precious metals. It can be collected and se- nt back to the manufacturer of it can be recast. These alloys are stable so it can be recast two or three times without much change in its composition. However, the more volatile base metals like zinc, indium, tin and iron may be lost. To compensate for this equal amount of new alloy should be added to the scrap during recasting. They should be carefully cleaned before reuse. Alloys of different types and manufacturers should not be mixed as it may change its composition and properties.

\section{Base metal alloys}

Base metal alloys have been the other group of alloys extensively instituted in dentistry. As these alloys are very reactive in nature, they form good chemical bond with porcelain and also have the advantage of good mechanical properties when used in specified proportions [21]. These are classified as nickel based, cobalt based, titanium and titanium based alloys. Alloys in both systems contain chromium as the second largest constituent.

\section{1. Nickel-chromium (Ni-Cr) System}

These metal-ceramic alloys offer such economy that they are also used for complete crown and all metal fixed partial dentures [22]. The major constituents are nickel and chromium, with a wide array of minor alloying elements. The composition of two types of $\mathrm{Ni}-\mathrm{Cr}$ alloys are shown in Figures 1 and 2. The system contains two major groups [22], those that contain Beryllium, and contain no Beryllium/Beryllium free. Among the two, Ni-Cr-Beryllium alloy are generally regarded as possessing superior properties and have been more popular [23].

Nickel-Chromium-Beryllium alloy is composed of 62 82\% Nickel, 11-20\% Chromium, 2\% of Beryllium and traces of minor alloying elements like, aluminium, carbon, iron, molybdenum etc. while the Beryllium free alloy has similar proportions of Nickel and Chromium without Beryllium and traces of Boron, Molybdenum, Niobium, Tantalum etc. This alloy system have low density and high sag resistance. The major drawback of the alloys is the oxide formation on the surface that causes bond failure between the alloy and the porcelain. The Beryllium containing alloy is more easily castable than the Beryllium free one. 


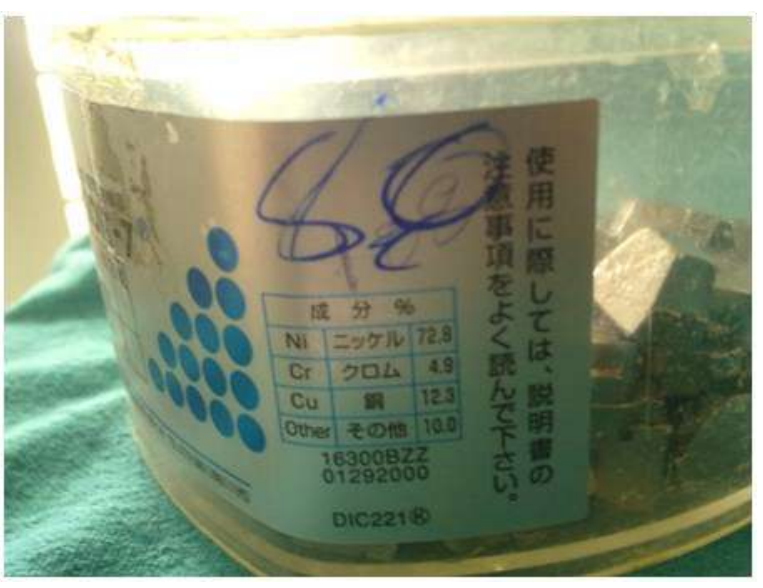

Figure 1. Ni-Cr pellets

\section{2. Cobalt-Chromium alloys}

Cobalt chromium alloys have been available since the 1920's. They possess high strength. Their excellent corrosion resistance especially at high temperatures makes them useful for a number of applications. These alloys are also known as 'satellite' because they maintained their shiny, star-like appearance under different conditions. They have bright lustrous, hard, strong and non-tarnishing qualities [24]. The applications find a wide range from partial denture frameworks to surgical implants. These alloys show similar properties as that of the Nickel-Chromium alloys.

The alloy contains Cobalt (55 to 65\%), Chromium (23 to $30 \%$ ), Nickel (0 to $20 \%$ ), Molybdenum (0 to $7 \%$ ), Iron ( 0 to $5 \%$ ), Carbon (up to $0.4 \%$ ) and Tungsten, Manganese, Silicon and Platinum in traces. According to A.D.A specification No. 14 a minimum of $85 \%$ by weight of chromium, cobalt, and nickel is required and classified based on fusion temperatures as type I High fusing and type II - Low fusing.

\section{3. Titanium and Titanium alloys}

Titanium is called "material of choice" in dentistry [25]. This is attributed to the oxide formation property which forms basis for corrosion resistance and biocompatibility of this material. The term 'titanium' is used for all types of pure and alloyed titanium. Commercially pure titanium is used for dental implants, surface coatings, crowns, partial dentures, complete dentures and orthodontic wires [26]. The following are the properties of titanium.

- Resistance to electrochemical degradation

- Begins biological response

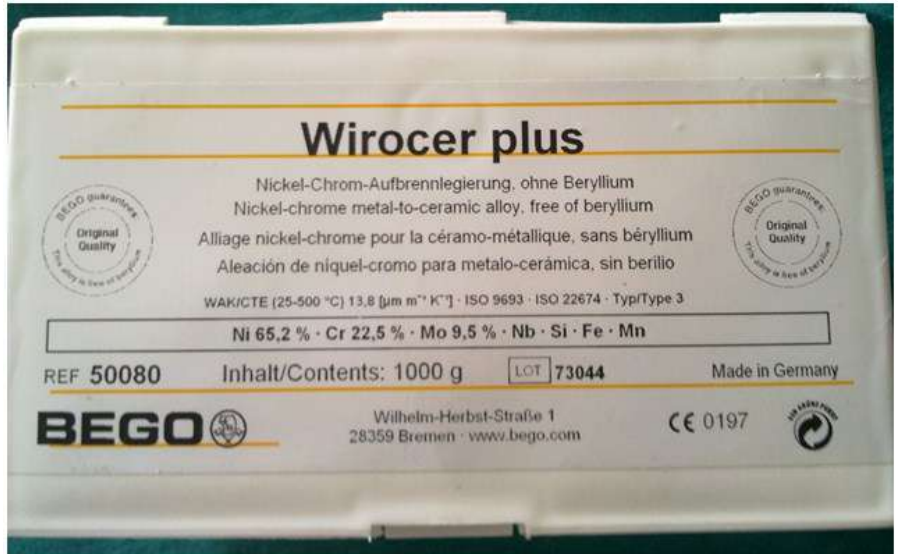

Figure 2. Be-free Ni-Cr alloy

- Relatively light weight

- Low density $\left(4.5 \mathrm{~g} / \mathrm{cm}^{3}\right)$

- Low modulus (100 GPa)

- High strength (yield strength = 170-480 MPa; ultimate strength $=240-550 \mathrm{MPa}$ )

- Passivity

- Low coefficient of thermal expansion $\left(8.5 \times 10-6 /{ }^{\circ} \mathrm{C}\right)$

- Melting \& boiling point of $1668^{\circ} \mathrm{C} \& 3260^{\circ} \mathrm{C}$

\subsubsection{Commercially Pure Titanium (CpTi)}

It is available in four grades (according to American Society for Testing and Materials ASTM) which vary according to the oxygen (0.18-0.40 wt.\%), iron (0.20$0.50 \mathrm{wt} \%$ ) and other impurities. It has got an alpha phase structure at room temperature and converts to beta phase structure at $883^{\circ} \mathrm{C}$ which is stronger but brittle [27].

\subsubsection{Titanium alloys}

Alloying elements are added to stabilize alpha or the beta phase by changing beta transformation temperature e.g. in Ti-6Al-4V, Aluminum is an alpha stabilizer whereas vanadium as well as copper and palladium are beta stabilizer. Alpha titanium is weld able but difficult to work with at room temperature. Beta titanium is malleable at room temperature and is used in orthodontics, but is difficult to weld [28]. Pure titanium is used to cast crowns, partial denture, and complete denture.

\subsubsection{Cast titanium}

Cast titanium has been used for more than 50 years, and it has been recently that precision casting can be 
obtained from it. The two most important factors in casting titanium-based materials are its high melting point $\left(1668^{\circ} \mathrm{C}\right)$ and chemical reactivity [27]. Because of the high melting point, special melting procedures, cooling cycles, mold materials, and casting equipments are required to prevent metal contamination, because it readily reacts with hydrogen, oxygen and nitrogen at temperatures greater than $600^{\circ} \mathrm{C}$. So casting is done in a vacuum or inert gas atmosphere. The investment materials such as phosphate bonded silica and phosphate investment material with added trace metal are used. It has been shown that magnesium-based investment cause internal porosity in casting. Because of its low density, it is difficult to cast in centrifugal casting machine. So advanced casting machine combining centrifugal, vacuum, pressure and gravity casting with electric arc melting technology have been developed.

\subsubsection{Difficulties in casting Titanium}

- High melting point

- High reactivity

- Low casting efficiency

- Inadequate expansion of investment

- Casting porosity

- Difficulty in finishing

- Difficulty in welding

- Require expensive equipment

A comparative assessment of the properties of different alloys mentioned in the article is illustrated in Table 4 .

\section{Biological hazards}

The potential hazards caused by casting alloys is due to beryllium and nickel content in the alloy. Other elements which elicit a irritant response are Palladium and Chromium. The dental laboratory technicians and patients are the two major groups at risk due to these hazards. Berylliosis and Contact dermatitis are caused by exposure to beryllium and nickel respectively [29]. Moffa et al (1973) reported that high levels of beryllium were accumulating during finishing and polishing when a local exhaust system was not used [30]. When an exhaust system was used, the concentration of beryllium in the breathing zone was reduced to levels considered safe by the authors. In 1982, Moffa et al reported that no correlation was found between the incidence of nickel sensitivity and the presence of intraoral nickel alloy prostheses [31].

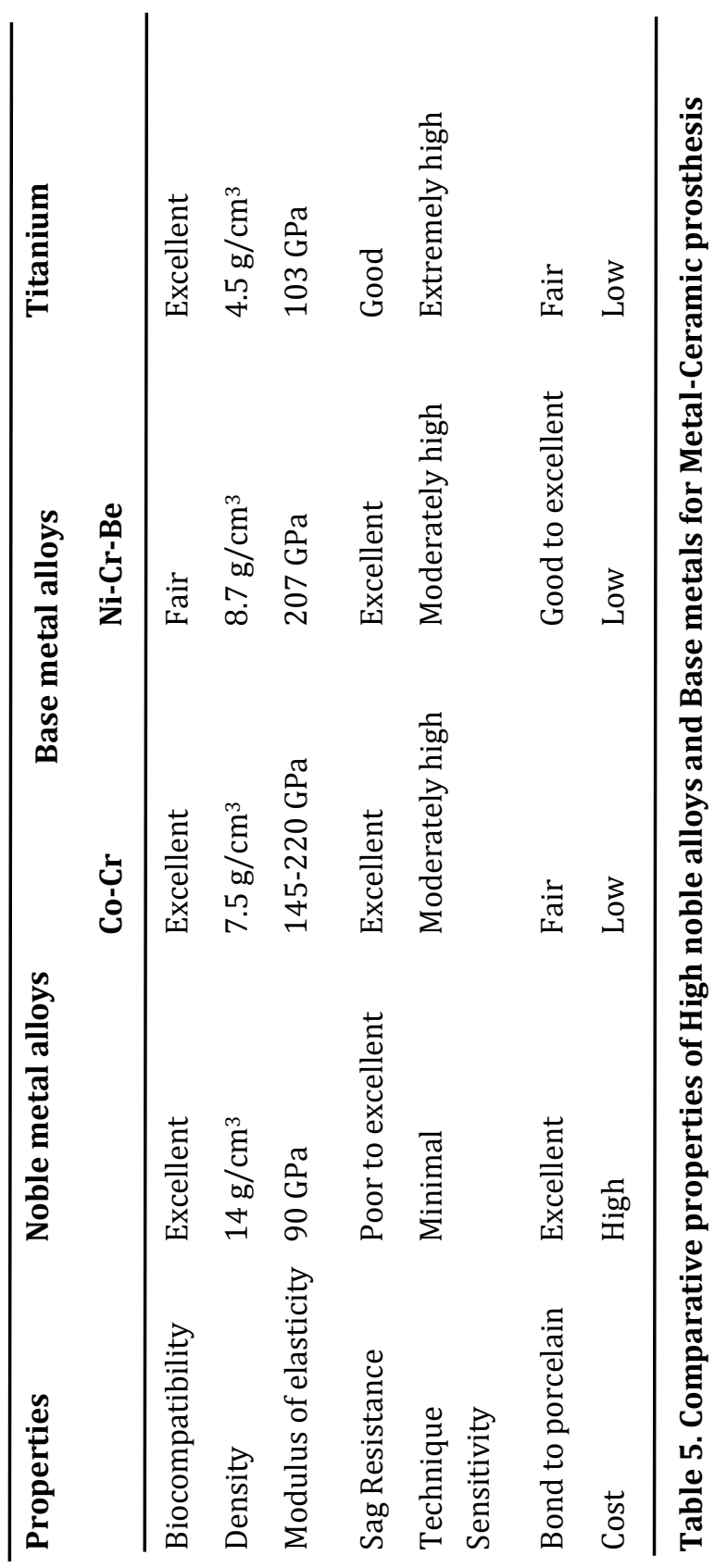

Vreeburg et al (1984) concluded that the oral exposure of nickel and chromium to guinea pigs via a fixed appliance or the dietary intake of these elements as metallic powder or salts did not induce an allergic reaction to these metals [32]. Even more significant is that subsequent attempts to elicit an allergic response in previously exposed animals generally failed, whereas unexposed animals exhibited a higher incidence of hypersensitive responses.

\subsection{OSHA (Occupational Safety and Health Administration) recommendations}

Exposure to beryllium dust in air should be limited to a particulate beryllium concentration of $2 \mu \mathrm{g} / \mathrm{m} 3$ of air (both respirable and nonrespirable particles) determined from an $8 \mathrm{~h}$ time-weighted average [33]. The 
existing OSHA standard specifies an 8-h timeweighted average (TWA) concentration limit of 1000 $\mu \mathrm{g} / \mathrm{m}^{3}$ or $1 \mathrm{mg} / \mathrm{m}^{3}$ of nickel and nickel compounds.

\subsection{NIOSH (National Institute for Occupa- tional Safety and Health) recommendations}

A limit of $0.5 \mu \mathrm{g} / \mathrm{m}^{3}$ based on a 130 -min sample in case of beryllium exposure and a standard to limit employee exposure to inorganic nickel in the laboratory or office to $15 \mu \mathrm{g} / \mathrm{m}^{3}$ (air), determined as a TWA concentration for up to a 10-h work shift (40-h work week) is recommended [34].

\section{Guidelines for selection of an alloy}

Practitioner should select the suitable alloy with consultation from the dental laboratory with primary concern towards the systemic health of the patient i.e. regarding any allergies. Next in order follow the desired physical, chemical and thermal properties which will influence the fit and durability of the restoration along with the esthetic and cost factors that finally decipher the appropriate alloy option [35].

\section{Conclusion}

Each alloy has specific physical and mechanical properties that affect its manipulation and application. Tooth preparation and restoration design will determine the required physical and mechanical properties of the alloy, so all factors should be kept in mind during selection of an alloy. Other technologies are currently available to avoid the challenges and cost associated with metal casting process.

\section{References}

1. Kenneth J Anusavice. Dental Casting and Soldering Alloys; Phillips' Science of Dental Materials; $11^{\text {th }}$ edition; Elsevier 2011.

2. John C. Wataha. Casting alloys; Dent Clin N Am 2004;48: 499-512.

3. Patel B, Mantri V: Dental Casting Alloy. National J Dent Sci Res. 2014; 1(2): 66-69.

4. https://en.wikipedia.org/wiki/ Alloy\#History and examples

5. Meng syn. A little history about dentistry Almaden Dental associates; Patient info www.scribd.com/ doc/71521265/Dental-Casting-Alloys
6. Moffa JP, Guckes AD, Okawa MT, Lilly GE. An evaluation of nonprecious alloys for use with porcelain veneers. Part II. Industrial safety and biocompatibility. J.Prosthet Dent. 1973; 30: 432.

7. Ronald L. Sakaguchi, John M. Powers. Restorative materials- Metals, Craig's Restorative dental materials; $13^{\text {th }}$ edition; Elsevier, 2012.

8. Leinfelder KF, O'Brien WJ, Taylor DF. Hardening of dental gold-copper alloys. J Dent Res. 1972; 51(4): 900-905.

9. Zhao Yao, Wu Bin, Meng Yukun. Influence of cryogenic treatment and age-hardening heat treatment on the corrosion behavior of a dental casting AgPd alloy. West China J Stomatol 2014; 32(3): 238241.

10. American Dental Association: Classification system for cast alloys. J AmDent Assoc 1984; 109:766.

11. Revised ANSI/ADA specification no. 5 for dental casting alloys. Council on Dental Materials, Instruments, and Equipment: J Am Dent Assoc. 1989; 118(3):379.

12. Yasuda K, Ohta M. Difference in Age-hardening Mechanism in Dental Gold Alloys. J Dent Res 61. 1982; 3:473-479.

13. Dental Product Spotlight: Dental casting alloys. J Am Dent Assoc. 2002; 133(6): 758-759.

14. Metals Handbook, Desk edition: Metals Park, OH, American Society of Metals, 1992.

15. Metals Handbook, Desk edition: Metals Park, OH, American Society of Metals, 1991.

16. Gettleman L. Noble alloys in dentistry, Curr Opin Dent: 1991; 2:218.

17. Smith DL. Dental casting alloys: technical and economic considerations in the USA. Int Dent J. 1983; 33(1):25-34.

18. Malhotra ML. Dental gold casting alloys: a review, Trends Tech Contemp Dent Lab. 1991;8:73.

19. Moffa JP. Alternative dental casting alloys. Dent Clin North Am. 1983; 27:733.

20. Kedici SP, Aksüt, AA, Kílíçarslan MA, Bayramog Lu G, Gökdemir K, Corrosion behaviour of dental metals and alloys in different media. J Oral Rehab. 1998;25(10): 800-808.

21. Marvin H. Goldfogel, John P. Nielsen: Dental casting alloys: An update on terminology. J Prosthet Dent, 48(3), 340-343.

22. Baran GR. The metallurgy of Ni-Cr alloys for fixed prosthodontics. J Prosthet Dent. 1983;50: 639.

23. Tuccillo JJ. Composition and functional characteristics of precious metal alloys for dental restoration 
In: Valega TM,ed. Alternatives to gold alloys in dentistry. Proceedings of a conference held at the National Institutes of Health. Bethesda (MD): DHEW publication new. (NIH) 77-1229, 40-67.

24. Roach M. Base metal alloys used for dental restorations and implants. Dent Clin N Am. 2007;51: 603.

25. Okabe $\mathrm{T}$, Hero $\mathrm{H}$. The use of titanium in dentistry. Cells Mater. 1995; 5:211.

26. Taira M, Moser JB, Greener EH. Studies of Ti alloys for dental castings. Dent Mater. 1989; 5:45.

27. Zavanelli RA, Henriques GEP, Ferreira I, Rollo JM. Corrosion fatigue life of commercially pure titanium and Ti-6Al-4V alloys in different storage environments. J Prosthet Dent. 2000; 84: 274-279.

28. S Gosavi, S Gosavi, R Alla. Titanium: A Miracle Metal in Dentistry. Trends Biomater Artif Organs, 2013; 27(1): 42-46.

29. Wataha, JC. Biocompatibility of dental casting alloys: A review. J Prosthet Dent. 2000; 83(2), 223234.

30. Moffa JP, Lugassy AA, Guckes AD, Gettleman L. An evaluation of nonprecious alloys for use with porcelain veneers. Part I. Physical properties. J Prosthet Dent. 1973; 30(4): 424-431.

31. Moffa JP Biological effects of nickel-containing dental alloys. Council on Dental Materials, Instruments, and equipment, J Am Dent Assoc. 1982; 104:50.

32. Vreeburg KJ, de Groot K, von Blomberg M, Scheper RJ. Induction of Immunological Tolerance by Oral Administration of Nickel and Chromium. J Dent Res. 1984; 63(2): 124-128.

33. U.S. Department of Labor, Occupational Safety and Health Administration: Hazard Information Bulletin 02-04-19 (rev. 05-14-02), Preventing adverse health effects from exposure to beryllium in dental laboratories, 2002. https://www.osha.gov/dts/ hib/hib data/hib20020419.html

34. Morris HF, Mann M, Stoffer W, Weir D. Casting Alloys: The Materials And "The Clinical Effects". Adv Dent Res. 1992; 6, 28-31.

35. Rama Krishna Alla: Dental Material Science. $1^{\text {st }}$ edition; Jaypee Medical publishers Pvt. Ltd., New Delhi, 2013. 